\title{
Analysis of Steroid Effect in Patients with Olfactory Dysfunction
}

\author{
Chang Bae Lee and Sangjun Kim \\ Department of Otolaryngology-Head and Neck Surgery, College of Medicine, Dong-A University, Busan, Korea
}

\section{후각장애 환자에서의 스테로이드 효과 분석}

이창배 · 김상준

동아대학교 의과대학 이비인후-두경부외과학교실

Received April 28, 2020

Revised October 7, 2020

Accepted November 24, 2020

Address for correspondence

Sangjun Kim, MD, MS

Departments of Otolaryngology-

Head and Neck Surgery,

College of Medicine,

Dong-A University,

26 Daesingongwon-ro, Seo-gu,

Busan 49201, Korea

Tel $+82-51-240-5428$

Fax $+82-51-253-0712$

E-mail ksjsj1010@naver.com
Background and Objectives Olfaction plays an important role on sensing and discriminating smell and taste. The number of patients visiting outpatient department for treatment of olfactory dysfunction is increasing along with the change in patients' perception about the importance of olfactory function.

Subjects and Method Patients with olfactory dysfunction, who visited the hospital from 2010 to 2018, were included in this study. The medical records were reviewed focusing on the Korean Version of Sniffin' Stick, the CT finding of olfactory cleft or signs of sinusitis, and the effect of oral steroids. Postviral olfactory disorder (PVOD) patients and chronic rhinosinusitis (CRS) patients were treated by oral steroid, starting on prednisolon (Solondo Tab ${ }^{\circledR}$, YuHan Corp.; $40 \mathrm{mg}$ per day) and tapered for 2 weeks.

Results There were 13 cases where patients' sense of smell was improved only for a short period of time after taking steroids but worsened thereafter. They showed improvement of olfactory function every time they took steroids. We defined this group as "steroid dependent olfactory dysfunction."

Conclusion It is necessary to understand the physiology and molecular biologic mechanisms behind the causes of olfactory dysfunction in order to establish the diagnostic criteria and treatment strategy. Steroid dependent olfactory dysfunction also needs more investigation.

Korean J Otorhinolaryngol-Head Neck Surg 2021;64(4):240-6

Key Words Olfaction · Olfaction disorder · Steroid.

\section{서 론}

인간의 후각 기능은 냄새와 향기를 맡고, 상한 음식을 감 별하거나, 음식의 맛을 느끼며, 가스 및 연기 냄새를 인지하 는 등의 중요한 역할을 한다. ${ }^{1)}$ 임상에서 후각 기능의 저하는 다른 질병과는 달리 쉽게 간과되는 경향이 많았다. 그러나 최근 들어 삶의 질 향상과 함께 음식의 미세한 맛, 향수의 섬 세한 차이의 구분을 요구하는 직업 등이 많아지고 있으며, 위

This is an Open Access article distributed under the terms of the Creative Commons Attribution Non-Commercial License (https://creativecommons.org/licenses/by-nc/4.0) which permits unrestricted non-commercial use, distribution, and reproduction in any medium, provided the original work is properly cited.
험한 상황에서의 노출을 피할 수 있게 해주는 점과 더불어, 후각의 중요성에 대한 환자들의 인식 변화와 함께 후각 치료 를 위해 외래를 찾는 환자들이 늘어나고 있는 추세이다.

후각장애의 원인은 다양하나 주로 상기도 감염 후에 바이 러스에 의한 후각손상(postviral olfactory disorder, PVOD), 비용종을 동반한 만성 부비동염(chronic rhinosinusitis with nasal polyp, CRS c NP), 비용종을 동반하지 않은 부비동염 (chronic rhinosinusitis without nasal polyp, CRS s NP), 머리외상(head trauma) 또는 원인을 알 수 없는 특발성(idiopathic) 등으로 크게 나뉠 수 있다. ${ }^{2)}$

후각장애 치료는 진단에 따라 치료가 다소 달라지게 되나, 
그 중 경구용 스테로이드 요법은 항염작용(anti-inflammatory property) 및 후각신경세포 회복 기전에 관여한다고 보 고되어 대부분의 후각장애 진단 군에서 공통적으로 널리 쓰 인다. ${ }^{3-6)}$

본 연구는 후각장애를 주소로 외래를 방문한 환자들을 원 인별로 나누어 분석하고, 이 중 스테로이드 의존성 후각장애 의 특징을 분석하여, 앞으로 후각장애 환자의 치료 계획을 정립하는 데 기초 자료를 수립하고자 시행하였다.

\section{대상 및 방법}

\section{기본 분석 방법}

2015 2018년 이비인후과 외래를 방문하여 후각저하나 후 각소실을 호소로 내원한 환자들 중, 후각 검사를 시행한 환 자를 대상으로 의무 기록을 통하여 후각장애의 원인별로 그 룹을 분류하였으며 병력, 이학적 검사 및 후각 검사 결과 등 을 후향적으로 분석하였다. 이 연구는 동아대학교병원의 IRB 승인을 받아 시행하였다(IRB No. DAUHIRB-19-147).

후각 검사는 한국형 후각 검사(Korean Version of Sniffin' Stick test II, KVSS-II)를 사용하였고, olfactory Threshold, odor Discrimination, odor Identification(TDI) score로 후 각장애의 정도를 측정하였다. TDI score는 정상후각은 30점 이상, 후각감퇴는 16 29점, 후각소실은 15점 이하로 하였다.

환자군 중 경구 스테로이드를 복용하였을 때 치료 기간 중 후각증상이 호전되었다가 치료가 끝나면 증상이 다시 악화 되어 장기적으로 2 회 이상 경구 스테로이드 요법을 시행한 환 자들을 스테로이드 의존적 후각장애(steroid dependent olfactory dysfunction)로 정의하고 추가로 조사하였다.

경구 스테로이드 치료는 일반적으로 2주일간 prednisolone $40 \mathrm{mg}$ (Solondo Tab ${ }^{\circledR}$; YuHan Corp., Seoul, Korea)을 하루 용량으로 시작해서 테이퍼링 요법을 실시하였다. 복용 전 기 저 질환과 피검사 및 가슴 방사선 사진을 기본적으로 확인한 후에 투여하였다.

통계 분석은 SPSS version 20.0 software(IBM Corp., Armonk, NY, USA)로 대응표본 t-검정과 Wilcoxon signedrank test를 이용하였고, 등분산 검정(Equal-variance test) 정규성 검정(Normality test)을 시행하였으며, $p<0.05$ 이하 시에 통계학적으로 유의하다고 간주하였다.

\section{결 과}

\section{처음 내원 당시 환자군의 특성}

대상 환자군은 총 184 명이었으며, 평균 연령은 48.62 세, 성
별로는 남자 92명, 여자 92명이었다. 주 호소 증상은 후각 증 상이 129 명이었고 후각장애의 정도는 무후각증(anosmia)이 61명, 후각저하(hyposmia)가 68명으로 이었으며, 다음으로 코막힘(nasal obstruction)이 31명으로 가장 많았다.

첫 방문 시 KVSS TDI score 전체 평균은 $18.16( \pm 10.32)$ 이 었으며, PVOD군은 평균 20.51( \pm 11.17$)$ 로 주 호소 증상은 48명 중 무후각증 14 명, 후각저하 23명이었고, CRS c NP군 은 17.3( \pm 3.83 )으로 46명 중 무후각증 10명, 후각저하 13명 이었으며, CRS s NP군은 20.92( \pm 6.65$)$ 로 39명 중 무후각증 6명, 후각저하 9명, allergic rhinitis(AR)군은 22.32( \pm 2.03$)$ 으 로 7예 중 후각저하가 7명, head trauma군은 10.55( \pm 6.66$)$ 으로 30예 중 무후각증 24명, 후각저하 6명, idiopathic군 5명 중 후각저하 3명, miscellaneous군 7예 중 무후각증 4명 후 각저하 1 명이었다.

총 환자 중 착후각(parosmia) 환자는 13 명이었으며 PVOD 군이 8명, CRS군이 4명이었다. 구체적인 냄새로는 화학약품 냄새 4명, 탄 냄새 2 명, 역한 냄새 2명, 가스 냄새 2명 등이었 다(Table 1).

\section{$\mathrm{PVOD}$ 환자군의 특성}

PVOD군의 경우 전체 48명 중 남자 14 명, 여자 34명이었고, 평균 연령은 50.89세였다. 증상이 시작된 계절은 여름(6 8월) 이 18명, 봄(3 5월)이 11명, 겨울(12 2월)이 10명, 가을(9 11 월)은 9명 순이었다. 후각저하 발생 시의 특성을 보았을 때 갑자기 후각저하를 인지한 경우(sudden onset)가 48명 중 36명이었다.

환자군 중 착후각(parosmia) 환자는 10 명이었으며, 모든 냄새가 각각 탄 냄새, 알코올 냄새, 가스 냄새 등으로 바뀌어 서 나는 경우가 많았다.

증상이 처음 시작된 후부터 외래 내원까지의 기간은 25.97 개월(0.25 240개월)이었다.

외래에서 경구용 스테로이드를 복용한 군은 38명이었고, 이중 경구 스테로이드가 주관적 증상 개선에 효과를 보인 환 자는 18명이었다. 스테로이드 복용한 군의 KVSS TDI score 평균은 내원 당시 $18.18( \pm 8.21)$ 에서 치료 후 $22.26( \pm 9.77)$ 이 었다 $(p=0.017)$.

전체 PVOD군의 내원하여 처음 검사한 KVSS TDI score 평균은 20.51( \pm 8.52$)$ 이었고, 평균 3 4개월 경과 뒤에 시행한 KVSS TDI score는 22.27( \pm 9.76$)$ 이었다 $(p=0.163)$ (Table 2).

\section{$\mathrm{CRS}$ 환자군의 특성}

$\mathrm{CRS}$ 군은 총 85명으로 비용종을 동반한 그룹(CRS c NP) 46명과 비용종을 동반하지 않은 그룹(CRS s NP)로 39명으 
Table 1. Characterisitics of enrolled subjects

\begin{tabular}{|c|c|}
\hline Subject & Number \\
\hline \multicolumn{2}{|l|}{$\operatorname{Sex}(n=184), \%$} \\
\hline Male & $92(50)$ \\
\hline Female & $92(50)$ \\
\hline Total & 184 \\
\hline Male sex (\%) & 50 \\
\hline \multicolumn{2}{|c|}{ Chief complain for visit } \\
\hline Anosmia & 61 \\
\hline Hyposmia & 68 \\
\hline Nasal obstruction & 31 \\
\hline PND & 5 \\
\hline Headache & 6 \\
\hline Rhinorrhea & 6 \\
\hline Snoring & 1 \\
\hline ETC & 6 \\
\hline \multicolumn{2}{|l|}{ Onset characteristics } \\
\hline Sudden onset & 72 \\
\hline Sudden insight & 97 \\
\hline Progressive & 13 \\
\hline Parosmia & 13 \\
\hline \multicolumn{2}{|l|}{ Past Hx. } \\
\hline DM & 9 \\
\hline HTN & 21 \\
\hline \multicolumn{2}{|l|}{ Diagnosis } \\
\hline PVOD & 48 \\
\hline CRS C NP & 46 \\
\hline CRS S NP & 39 \\
\hline $\mathrm{AR}$ & 7 \\
\hline Trauma & 30 \\
\hline Idiopathic & 5 \\
\hline Miscellaneous & 7 \\
\hline
\end{tabular}

PND: post-nasal drip, Hx: history, DM: diabetes mellitus, HTN: hypertension, PVOD: postviral olfactory disorder, CRS C NP: chronic rhinosinusitis with nasal polyp, CRS S NP: chronic rhinosinusitis without nasal polyp, AR: allergic rhinitis

로 나누어서 조사하였다.

CRS c NP 그룹의 내원 시 주호소 증상은 후각저하 13명, 무후각 10 명, 코막힘이 15 명 등이었다.

부비동 방사선단층촬영(PNS CT)상 Lund-Mackay score 의 평균은 우측이 4.67점, 좌측이 4.54점이었으며, 후열(olfactory cleft)의 흐리기(haziness)는 46예 중 25예가 관찰되었다. 치료는 항생제만 쓰고 좋아진 경우가 3예, 부비동 내시경 수 술(functional endoscopic sinus surgery, FESS)을 하고 호 전을 보인 경우가 13예였으며, 수술 이후에 호전이 없어서 스 테로이드를 복용한 경우는 총 30예였다. 2주 이상의 경구 스 테로이드 복용에서 효과를 보인 환자는 22예, 효과가 전혀 없는 경우는 6예였다. 경구 스테로이드를 복용한 환자군 중 스테로이드를 복용하는 당시에 후각의 호전을 보였다가 수
Table 2. Characteristic of postviralolfactory disorder group

\begin{tabular}{|c|c|}
\hline Subject & Number \\
\hline \multicolumn{2}{|l|}{$\operatorname{Sex}(n=48)$} \\
\hline Male & 14 \\
\hline Female & 34 \\
\hline Age, yrs (average) & 50.89 \\
\hline Male & 48.35 \\
\hline Female & 51.94 \\
\hline \multicolumn{2}{|l|}{ Onset season } \\
\hline Spring $(3-5)$ & 11 \\
\hline Summer (6-8) & 18 \\
\hline Autumn $(9-11)$ & 9 \\
\hline Winter (12-2) & 10 \\
\hline \multicolumn{2}{|l|}{ Onset characteristics } \\
\hline Sudden onset & 36 \\
\hline Sudden insight & 10 \\
\hline Progressive & 2 \\
\hline Parosmia & 10 \\
\hline Phantosmia & 0 \\
\hline \multicolumn{2}{|l|}{ Past Hx. } \\
\hline DM & 4 \\
\hline HTN & 5 \\
\hline Total number of steroid-treated patient & 38 \\
\hline Patients with steroid effect & 18 \\
\hline Patients without steroid effect & 11 \\
\hline Patients unsure about steroid effect & 7 \\
\hline Patients without steroid treatment & 2 \\
\hline Follow up days average (mo) & 3.85 \\
\hline $\begin{array}{l}\text { Period from start of symptoms to visit the } \\
\text { hospital (mo) }\end{array}$ & 25.97 \\
\hline \multicolumn{2}{|l|}{ KVSS } \\
\hline KVSS (before treatment) & $18.18( \pm 8.21)$ \\
\hline KVSS (after treatment) & $22.27( \pm 9.76)$ \\
\hline
\end{tabular}

mo: month, Hx: history, DM: diabetes mellitus, HTN: hypertension, KVSS: Korean Version of Sniffin' Stick

개월 뒤 다시 증상이 악화되어 재복용한 사례는 12 예였으며, 이중 8예에서 경구 스테로이드를 복용하고 치료 기간에만 후 각 증상이 호전되는 steroid dependent olfactory dysfunction을 보였다. CRS c NP 환자 중 스테로이드를 복용한 군의 KVSS TDI score 변화 평균은 치료 전 $15.40( \pm 8.76)$, 치료 후 $22.28( \pm 10.67)$ 이었다 $(p=0.050)$. 전체 CRS c NP 환자의 내원 초기와 치료 후 KVSS TDI 변화 평균은 $17.8( \pm 13.69)$ 에서 24.56 $( \pm 10.98)$ 였다 $(p=0.185)$ (Table 3).

무후각증을 호소한 군 $(\mathrm{n}=7)$ 에서 스테로이드를 복용한 그 룹의 KVSS TDI score 평균은 17.9( \pm 3.83$)$ 이었고 3개월 후 변화 평균은 $16.13( \pm 9.47)$ 이었다 $(p=0.126)$. 후각저하를 호소 한 군 $(\mathrm{n}=10)$ 에서는 $25.64( \pm 5.84)$ 에서 $22.45( \pm 12.35)$ 로 변화가 있었다 $(p=0.738)$ (Table 4). 
Table 3. Characteristics of chronic rhinosinusitis with nasal polyp groups

\begin{tabular}{|c|c|}
\hline Subject & Number \\
\hline \multicolumn{2}{|l|}{$\operatorname{Sex}(n=46)$} \\
\hline Male & 29 \\
\hline Female & 17 \\
\hline Age, yrs (average) & 48.13 \\
\hline Male & 46.84 \\
\hline Female & 49.58 \\
\hline \multicolumn{2}{|l|}{ Chief complain for visit } \\
\hline Anosmia & 10 \\
\hline Hyposmia & 13 \\
\hline Nasal obstruction & 15 \\
\hline PND & 5 \\
\hline Headache & 2 \\
\hline Rhinorrhea & 1 \\
\hline Parosmia & 2 \\
\hline \multicolumn{2}{|l|}{ Past Hx. } \\
\hline $\mathrm{DM}$ & 1 \\
\hline HTN & 5 \\
\hline \multicolumn{2}{|l|}{ Lund-Mackay score } \\
\hline Right & 4.67 \\
\hline Left & 4.54 \\
\hline Olfactory cleft hazziness & 25 \\
\hline \multicolumn{2}{|l|}{ Treatment } \\
\hline Anti (only) & 3 \\
\hline FESS (without steroid treatment) & 13 \\
\hline Total number of steroid-treated patient & 30 \\
\hline Patients with steroid effect & 22 \\
\hline Patients without steroid effect & 6 \\
\hline Patients unsure about steroid effect & 2 \\
\hline High dose steroid (from 40 mg start) & 29 \\
\hline Low dose steroid (from 20 mg start) & 1 \\
\hline Steroid use more than twice ( $2-5$ times) & 12 \\
\hline Steroid dependent olfactory dysfunction & 8 \\
\hline \multicolumn{2}{|l|}{ KVSS (total) } \\
\hline KVSS (before treatment) & $17.8( \pm 13.69)$ \\
\hline KVSS (after treatment) & $24.56( \pm 10.98)$ \\
\hline
\end{tabular}

PND: post-nasal drip, Hx: history, DM: diabetes mellitus, HTN: hypertension, FESS: functional endoscopic sinus surgery, KVSS: Korean Version of Sniffin' Stick
CRS s NP 그룹 중 주호소 증상은 후각저하 18명, 무후각 10 명, 코막힘 6명 순이었다. 부비동 방사선단층촬영(PNS CT) 상 Lund-Mackay score의 평균은 우측 3.05, 좌측이 2.65였 으며, 후열의 흐리기는 39예 중 19예가 관찰되었다. 치료는 항 생제만 쓰고 좋아진 경우가 3예, 부비동 내시경 수술을(FESS) 하고 호전을 보인 경우가 5예였으며, 수술 이후에 호전이 없 어서 스테로이드를 복용한 경우는 총 27예였다. 2주 이상의 경구 스테로이드 복용에서 효과를 보인 환자는 11예, 효과가 전혀 없는 경우는 3예였다. 스테로이드를 복용한 환자군 중 복용 당시에 후각의 호전을 보였다가, 다시 증상이 악화되어 재복용한 경우는 9예였으며, 이 중 5명에서 스테로이드 의존 적인 후각증상의 호전을 보였다. CRS s NP 환자의 스테로이 드를 복용한 군의 KVSS TDI score 변화 평균은 치료 전 $19.26( \pm 8.35)$ 에서 치료 후 22.04( \pm 9.01$)$ 였다 $(p=0.377)$. 전체 CRS s NP 환자의 내원 초기와 치료 후 KVSS TDI score 변 화 평균은 26.00( \pm 11.99$)$ 에서 22.04( \pm 9.01$)$ 였다 $(p=0.449)$ (Table 5).

스테로이드를 복용한 군의 평균은 무후각을 호소한 군 $(\mathrm{n}=2)$ 에서 10.5( \pm 2.12$)$ 였고, 3개월 후 변화 평균은 9.25( \pm 2.47$)$ 였 다 $(p=0.126)$. 후각저하를 호소한 군 $(\mathrm{n}=5)$ 에서는 KVSS TDI score가 22.76( \pm 7.06$)$ 에서 27.16( \pm 2.39$)$ 으로 변화가 있었다 ( $p=0.328)$ (Table 4). 반면 스테로이드를 복용하지 않은 군은 무후각을 호소한 그룹 $(\mathrm{n}=4)$ 에서는 9.125( \pm 3.12$)$ 였고, 이후 추가적인 KVSS 검사를 시행한 환자는 없었다. 후각저하군 $(\mathrm{n}=4)$ 에서는 $28.6( \pm 5.12)$ 에서 $35.2( \pm 4.25)$ 로 변화가 있었다 $(p=0.347)$.

$\mathrm{CRS}$ 군 중 무후각증과 후각저하를 호소한 환자들의 측면 에서 스테로이드 사용을 분석해보면, $\mathrm{CRS} \mathrm{c} \mathrm{NP군에서는} \mathrm{무}$ 후각증을 호소한 27명 중 스테로이드를 사용한 환자군은 18 명이었고, 이 중 주관적인 반응이 좋았던 환자는 15 명이었 으며, 이 중 7명에서 이후 후각 증상 악화되어 2회 이상 재복 용하였다. 후각저하를 호소한 19명 중 12명에서 스테로이드를 사용하였으며 이 중 6명에서 스테로이드에 대한 반응이 좋았 으며, 이 중 3 명에서 2 회 이상 스테로이드를 재복용하였다.

Table 4. Change in KVSS TDI score before and after steroid treatment (chronic rhinosinusitis group)

\begin{tabular}{lccc}
\hline & Before treatment KVSS TDI score & After treatment KVSS TDI score (after 3 mo) & $p$ value \\
\hline CRS c NP group & & & 0.126 \\
Anosmia $(n=7)$ & $17.9( \pm 3.83)$ & $16.13( \pm 9.47)$ & 0.738 \\
Hyposmia $(n=10)$ & $25.64( \pm 5.84)$ & $22.45( \pm 2.35)$ & 0.126 \\
CRS s NP group & & & 0.328 \\
Anosmia $(n=2)$ & $10.5( \pm 2.12)$ & $9.25( \pm 2.47)$ & $27.16( \pm 2.39)$ \\
Hyposmia $(n=5)$ & $22.76( \pm 7.06)$ & & \\
\hline
\end{tabular}

KVSS: Korean Version of Sniffin' Stick, TDI: olfactory Threshold, odor Discrimination, odor Identification, CRS c NP: chronic rhinosinusitis with nasal polyp, CRS s NP: chronic rhinosinusitis without nasal polyp 
Table 5. Characteristics of chronic rhinosinusitis without nasal polyp groups

\begin{tabular}{|c|c|}
\hline Subject & Number \\
\hline \multicolumn{2}{|l|}{$\operatorname{Sex}(n=39)$} \\
\hline Male & 20 \\
\hline Female & 19 \\
\hline Age, yrs (average) & 50 \\
\hline Male & 43.84 \\
\hline Female & 55.85 \\
\hline \multicolumn{2}{|l|}{ Chief complain for visit } \\
\hline Anosmia & 10 \\
\hline Hyposmia & 18 \\
\hline Nasal obstruction & 6 \\
\hline PND & 1 \\
\hline Headache & 0 \\
\hline Rhinorrhea & 4 \\
\hline ETC & 0 \\
\hline Parosmia & 3 \\
\hline \multicolumn{2}{|l|}{ Past Hx. } \\
\hline $\mathrm{DM}$ & 3 \\
\hline HTN & 2 \\
\hline \multicolumn{2}{|l|}{ Lund-Mackay score } \\
\hline Right & 3.05 \\
\hline Left & 2.65 \\
\hline Olfactory cleft hazziness & 19 \\
\hline \multicolumn{2}{|l|}{ Treatment } \\
\hline Anti (only) & 3 \\
\hline FESS (without steroid treatment) & 5 \\
\hline Total Number of steroid-treated patient & 27 \\
\hline Patients with steroid effect & 11 \\
\hline Patients without steroid effect & 3 \\
\hline Patients unsure about steroid effect & 3 \\
\hline High dose steroid (from 40 mg start) & 25 \\
\hline Low dose steroid (from 20 mg start) & 2 \\
\hline Steroid use more than twice $(2-5)$ & 9 \\
\hline Steroid dependent olfactory dysfunction & 5 \\
\hline \multicolumn{2}{|l|}{ KVSS } \\
\hline KVSS (before treatment & $26.00( \pm 11.99)$ \\
\hline KVSS (after treatment) & $22.04( \pm 9.01)$ \\
\hline
\end{tabular}

PND: post-nasal drip, Hx: history, DM: diabetes mellitus, HTN: hypertension, FESS: functional endoscopic sinus surgery, KVSS: Korean Version of Sniffin' Stick

CRS s NP군에서는 무후각증을 호소한 14명 중 스테로이 드는 8 명에서 복용을 하였으며 이 중 2명에서 반응이 좋았고 이후 다시 후각저하 증상이 있어 다시 스테로이드를 복용하 였다. 후각저하 군 28 명 중 스테로이드를 복용한 군은 19명 이었으며 이 중 9명에서 주관적인 후각 개선 효과를 보였고 이 중 6 명에서 다시 증상 악화되어 2회 이상 스테로이드를 재 복용하였다.
Table 6. Lund-Mackay score differences between steroid effective groups and in effective groups (chronic rhinosinusitis group)

\begin{tabular}{lcc}
\hline Steroid effect (subjective) & Lund-Mackay score & p value \\
\hline CRS c NP & & 0.328 \\
Effect $(n=9)$ & $8.11( \pm 6.07)$ & \\
$\quad$ No effect $(n=21)$ & $10.42( \pm 6.74)$ & \\
CRS s NP & & 0.149 \\
Effect $(n=16)$ & $4.5( \pm 6.77)$ & \\
No effect $(n=11)$ & $6.9( \pm 5.56)$ & \\
CRS c NP: chronic rhinosinusitis with nasal polyp, CRS S NP: \\
chronic rhinosinusitis without nasal polyp
\end{tabular}

Table 7. Trauma groups

\begin{tabular}{lc}
\hline \multicolumn{1}{c}{ Subject } & Number \\
\hline Sex & \\
Male & 21 \\
Female & 9 \\
Age (age) & 46.6 \\
Male & 45.19 \\
Female & 50.11 \\
Olfactory cleft hazziness & 0 \\
Korean Version of Sniffin' Stick & $10.55( \pm 6.66)$
\end{tabular}

$\mathrm{CRS}$ 환자 중 스테로이드 의존성 후각 증상을 보인 13명 중 남성은 9명, 여성은 4명이었으며, 부비동단층촬영(PNS CT)상 Lund-Mackay score의 평균은 우측 5.15, 양측 5.15였으며, 후열의 흐리기는 13예 중 7예에서 관찰되었다. 이 중 KVSS TDI score의 평균 변화는 처음 내원 시에 15.63에서 약물 복 용 후 마지막 호전 시의 KVSS 평균 TDI score는 20.23이었 다. 경구 스테로이드는 적게는 2 회에서 많게는 5 회까지 5 개월 이상의 기간을 경구 스테로이드를 반복 사용하였다(초기 스 테로이드 $20 \mathrm{mg}$ 테이퍼링은 3 명, $40 \mathrm{mg}$ 은 10명이었다).

스테로이드 처방 효과에 따른 초기 Lund-Mackay score 를 보았을 때 $\mathrm{CRS} \mathrm{c} \mathrm{NP군에서} \mathrm{스테로이드} \mathrm{복용} \mathrm{후} \mathrm{주관적}$ 인 후각의 호전을 보이는 군의 Lund-Mackay score 평균은 8.11( \pm 6.07$)$ 이었고, 효과가 없는 군의 평균은 $10.42( \pm 6.74)$ 였 다 $(p=0.328) . \mathrm{CRS} \mathrm{s} \mathrm{NP}$ 군에서는 스테로이드 복용 후 주관 적인 후각의 호전을 보이는 군의 Lund-Mackay score 평균 은 4.5( \pm 6.77$)$ 였고, 효과가 없는 군의 평균은 $6.9( \pm 5.56)$ 였다 ( $p=0.149)$ (Table 6).

\section{기 타}

Head trauma군 환자는 총 30 예였으며, 후각 검사상 10.55 ( \pm 6.66$)$ 경구 스테로이드치료를 시행하지는 않았다(Table 7). 그 외 $\mathrm{AR}$ 군에서도 후각의 장애를 보인 환자가 7예 있었다. 


\section{고 찰}

후각장애의 원인 중 가장 많은 원인은 $\mathrm{PVOD}$ 라고 하였으 나 ${ }^{1)}$ 본 연구에서는 PVOD가 48예, 만성 부비동염 환자가 85 예로 더 많이 집계 되었는데(Fig. 1), 그 원인은 수술을 위해 서 대학병원을 찾는 환자의 수가 많은 의료시스템 때문이라 고 예측된다.

$\mathrm{PVOD}$ 는 심한 감기나 독감 뒤에 발생하게 되며 후각 상피 세포나 후구(olfactory bulb)에 손상이 있을 것으로 추측하고 있다. 아직 정확한 기전은 알려져 있지 않으나 치료에는 경구 용 스테로이드나 국소용 스테로이드가 사용되고 있으며 후열 영역 주변으로 스테로이드 용액을 주입하는 케이스도 보고 된다. $\mathrm{PVOD}$ 의 예후는 다른 군보다는 자연적 회복이 가능하 다고 하나 $30 \%$ 에서 장기적으로 걸쳐서 서서히 회복된다. ${ }^{2}$ 발 병한 계절은 여름이 많았으며 증상 시작 후 외래 방문 시간까 지의 시간은 평균 25 개월이었으나, 초기 치료가 빠를수록 예 후가 좋아진다는 보고도 있어 ${ }^{8}$ 증상 시작 후 외래 내원 기간 을 줄여야 할 필요성이 있다. 본 연구에서 경구용 스테로이드 치료를 한 38 명의 환자 중, 18 명의 환자가 주관적으로 증상의 회복이 있었으며, 3 6개월 이후 KVSS TDI score의 변화는 20.51에서 22.26로 다소 호전은 있었다. 또한 상기도 호흡기 감염에서 후각 기능 회복은 1년 이상에 걸쳐서 서서히 일어 난다는 보고가 있어 향후 더 호전이 있을 것으로 기대한다. ${ }^{9}$ 치료에 있어서 아직 $\mathrm{PVOD}$ 의 정립된 protocol은 없는 실정이 다. Schriever의 후향적 연구에 따르면 스테로이드(methylprednisolone) $40 \mathrm{mg}$ 을 2주간 테이퍼링 하면서 증상의 호전

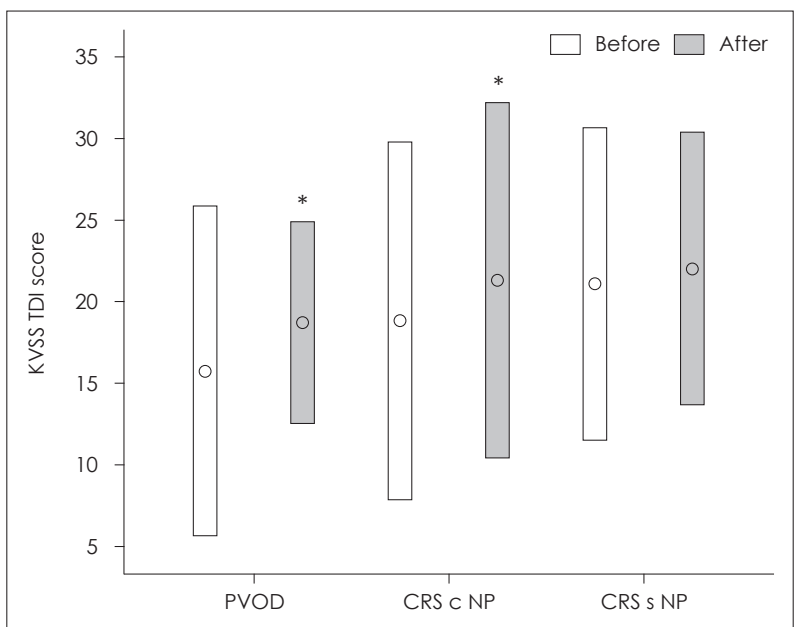

Fig. 1. Comparison of KVSS TDI score between before and after steroid treatment in PVOD, CRS c NP, CRS s NP groups. *it shows statistical significance $(p<0.05)$. KVSS: Korean Version of Sniffin' Stick, TDI: olfactory Threshold, odor Discrimination, odor Identification, PVOD: postviral olfactory disorder, CRS c NP: chronic rhinosinusitis with nasal polyp, CRS s NP: chronic rhinosinusitis without nasal polyp.
을 보였다는 연구도 있으며 ${ }^{10)} \mathrm{Seo}$ 등 $^{11)}$ 의 연구에서 gink gil$\mathrm{oba}$ 를 병행하는 치료도 효과가 있다는 보고도 있다.

만성 부비동염(CRS)에서 후각장애의 기전은 아직 명확히 알려져 있지 않으나 비용종(nasal polyp)이나 점막의 비후에 의해서 후열로 가는 기류의 방해로 인한 전도성 후각장애 또 는 후각신경세포의 손상에 의한 것이라는 발표도 있다. ${ }^{12,13)}$ 치료 약물이 효과가 없을 경우 수술을 병행 하기도 하는데, 후각 호전을 하는데 있어서의 수술은 수술 후 비강 내부 점 막의 유착으로 인해 후각 장애의 호전이 미미하다는 보고도 있으나, ${ }^{14)}$ 비용종 환자에서 중비갑개를 절제하는 것이 후각 향상에 도움이 되었다는 보고도 있다. ${ }^{15)}$ 또한 비용종의 유무 에 상관 없이 스테로이드 치료가 효과적이라는 발표도 있 다. ${ }^{16)}$ 본 연구에서도 57 명의 부비동염 환자 중 스테로이드를 치료한 군에서 33명이 각각 정도는 달랐지만 후각 호전 증상 을 보였다.

본 연구에서는 $\mathrm{CRS}$ 군에서 경구 스테로이드 치료를 하고 난 뒤, 2 5개월 동안은 후각 증상이 개선되었다가 추후에 다 시 증상이 다시 악화되는 경우가 있었으며, 경구 스테로이드 치료를 시행한 환자 중 13 명은 경구 스테로이드에 의존적으 로 후각증상이 개선 되었는데 이 환자들은 2 5차례 이상 경 구 스테로이드(40 mg tapering)를 장기간에 걸쳐서 반복적 으로 복용하였다. 이러한 경우를 스테로이드 의존성 후각장 애로 정의하였다. 이는 비강 내의 비대한 점막 수축, 염증 감 소, 후각 신경의 회복 과정에 스테로이드가 작용할 것으로 사 료되지만 반복적으로 호전 악화 되는 기전에 대해서 발표한 사례는 아직 없는 실정이다.

두부외상이 후각장애의 원인인 경우 후각소실(anosmia)이 많으며 예후도 좋지 않다고 보고 된다. ${ }^{9)}$ 예상되는 기전은 후 각 섬유원(olfactory fibers)의 외부 충격으로 인한 축삭의 퇴화로 후각장애가 발생, 또는 비골 골절이나 안면부 골절로 내부 후열로의 기류장애에 의한 것으로 추정하고 있다. ${ }^{17)}$ 본 연구에서도 두부외상에 의한 후각장애 환자들의 평균은 KVSS TDI score는 11.55로 다른 그룹보다 낮게 측정되었다.

이 연구에서 저자들은 $\mathrm{PVOD}$ 및 $\mathrm{CRS}$ 군 각각에서 스테로 이드를 복용한 그룹과 복용하지 않은 그룹에서 KVSS TDI score 추이를 비교해보고자 하였으나, 외래에서 후각 검사 비 용 및 치료하지 않은 환자의 follow-up 문제로, 같은 기간 동 안의 KVSS TDI score는 비교할 수 없다는 한계점이 있었다. 그래서 PVOD, CRS c NP, CRS 각 군에서의 스테로이드 사용 결과 전·후를 비교하였을 때, KVSS TDI score의 개선도는 $\mathrm{CRS}$ c NP 그룹에서 가장 크게 나타났으며, 다음으로 PVOD 그룹이었다. $\mathrm{PVOD}$ 군 $(p=0.017)$ 과 $\mathrm{CRS} c \mathrm{NP}$ 군 $(p=0.050)$ 에 서 스테로이드 효과에서 유의한 결과를 얻었다(Fig. 2). 


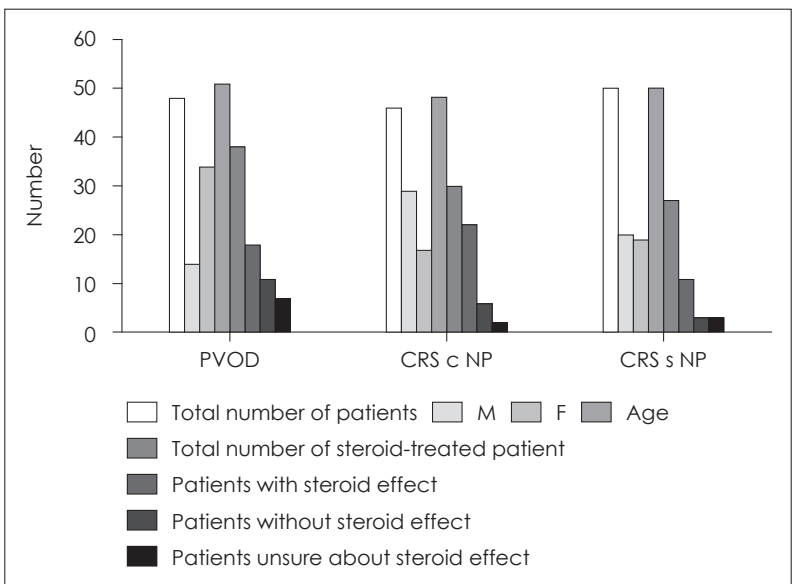

Fig. 2. Comparison of patients character in PVOD, CRS c NP and CRS s NP groups.PVOD: postviral olfactory disorder, CRS c NP: chronic rhinosinusitis with nasal polyp, CRS s NP: chronic rhinosinusitis without nasal polyp.

후각 장애는 현대 사회에서 다양한 원인으로 올 수 있으나, 치료를 시행한다 하여도 예후에 대한 환자의 회복율은 낮으 며, 아직까지 통일된 치료 프로토콜이 없는 것이 사실이다. 경구 스테로이드 치료 역시 후각장애에 있어서 널리 사용되 어 효과가 입증되고 있는 방법이기는 하나 아직까지 통일된 가이드라인이 없는 실정이다.

후각장애의 회복 속도가 느려서 회복이 된다 하더라도 1년 이상의 기간이 걸리는 경우가 대부분이며, 후각장애로 인해 서 타인과의 공감능력 저하로 우울증으로 이어지는 사례도 있어, 외래에서 의사가 후각장애 치료와 예후에 대한 적절한 상담 및 교육과 함께 환자와 보호자가 서로 이해를 할 수 있 는 기회를 마련해 주는 것도 중요할 것이다.

최근에는 후각세포의 가소성에 기반을 둔 후각훈련법(olfactory training)으로 후각장애에 효과가 있다는 지견도 있 어, ${ }^{18)}$ 경구 스테로이드 치료와 함께 후각훈련법을 교육하는 것도 도움이 될 것으로 보인다.

결론적으로, 본 연구에서는 후각장애 환자들을 원인에 따 라 그룹별로 분류하여 분석하고자 하였다. 스테로이드 복용 후에 후각 개선에 유의하게 효과를 보였던 그룹은 PVOD와 $\mathrm{CRS} \mathrm{c} \mathrm{NP군이었다.} \mathrm{후각장애} \mathrm{환자에서의} \mathrm{스테로이드} \mathrm{복용}$ 은 많은 문헌에서 효과가 있다고 보고되고 있으나, 아직까지 도 후각장애 환자에서 스테로이드 효과에 대한 생리학 및 분 자세포학적 기전에 대한 명확한 메커니즘은 발표되지 않았 다. 더욱이 본 연구에서 $\mathrm{CRS}$ 군에서의 스테로이드 의존성 후 각장애처럼 복용 유무에 따라 계속적으로 후각 변동이 되는 현상에 대한 기전은 아직 명확하게 밝혀지지 않아, 추후 지 속적인 연구가 필요할 것으로 보인다. 후각장애 환자에서 스 테로이드 효과에 대한 다양한 연구와 함께 진단 및 치료 프 로토콜의 정립이 요구된다.

\section{Acknowledgments}

This work was supported by the Dong-A University research fund.

\section{Author Contribution}

Conceptualization: all authors. Data curation: Chang Bae Lee. Formal analysis: Sangjun Kim. Funding acquisition: Sangjun Kim. Investigation: all authors. Resources: Chang Bae Lee. Supervision: Sangjun Kim. Validation: Sangjun Kim. Visualization: Chang Bae Lee. Writing — original draft: Chang Bae Lee. Writing—review \& editing: Sangjun Kim.

\section{ORCID}

Sangjun Kim https://orcid.org/0000-0002-6025-6775

\section{REFERENCES}

1) Croy I, Symmank A, Schellong J, Hummel C, Gerber J, Joraschky $\mathrm{P}$, et al. Olfaction as a marker for depression in humans. J Affect Disord 2014;160:80-6.

2) Hong SC. Diagnosis and treatment of the olfactory disturbances. J Clinical Otolaryngol 1999;10(1):28-35.

3) Gaines AD. Anosmia and hyposmia. Allergy Asthma Proc 2010; 31(3):185-9.

4) Nishimura T, Teranishi S, Kawashima A, Ishimaru T, Miwa T, Furukawa M. Glucocorticoid enhances $\mathrm{Na}(+) / \mathrm{K}(+)$ ATPase mRNA expression in rat olfactory mucosa during regeneration: a possible mechanism for recovery from olfactory disturbance. Chem Senses 2002;27(1):13-21.

5) Sultan B, May LA, Lane AP. The role of TNF- $\alpha$ in inflammatory olfactory loss. Laryngoscope 2011;121(11):2481-6.

6) Buck L, Axel R. A novel multigene family may encode odorant receptors: A molecular basis for odor recognition. Cell 1991;65(1): 175-87.

7) Hong SC, Yoo YS, Kim ES, Kim SC, Park SH, Kim JK, et al. Development of KVSS Test (Korean Version of Sniffin' Sticks Test). Korean J Otolaryngol 1999;42(7):855-60.

8) Kim DH, Kim SW, Hwang SH, Kim BG, Kang JM, Cho JH, et al. Prognosis of olfactory dysfunction according to etiology and timing of treatment. Otolaryngol Head Neck Surg 2017;156(2):371-7.

9) Duncan HJ, Seiden AM. Long-term follow-up of olfactory loss secondary to head trauma and upper respiratory tract infection. Arch Otolaryngol Head Neck Surg 1995;121(10):1183-7.

10) Schriever VA, Merkonidis C, Gupta N, Hummel C, Hummel T. Treatment of smell loss with systemic methylprednisolone. Rhinology 2012;50(3):284-9.

11) Seo BS, Lee HJ, Mo JH, Lee CH, Rhee CS, Kim JW. Treatment of postviral olfactory loss with glucocorticoids, Ginkgo biloba, and mometasone nasal spray. Arch Otolaryngol Head Neck Surg 2009; 135(10):1000-4

12) Raviv JR, Kern RC. Chronic rhinosinusitis and olfactory dysfunction. Adv Otorhinolaryngol 2006;63:108-24.

13) Raviv JR, Kern RC. Chronic sinusitis and olfactory dysfunction. Otolaryngol Clin North Am 2004;37(6):1143-57, v-vi.

14) Downey LL, Jacobs JB, Lebowitz RA. Anosmia and chronic sinus disease. Otolaryngol Head Neck Surg 1996;115(1):24-8.

15) Jankowski R, Bodino C. Olfaction in patients with nasal polyposis: effects of systemic steroids and radical ethmoidectomy with middle turbinate resection (nasalization). Rhinology 2003;41(4):220-30.

16) Alobid I, Mullol J. Role of medical therapy in the management of nasal polyps. Curr Allergy Asthma Rep 2012;12(2):144-53.

17) Howell J, Costanzo RM, Reiter ER. Head trauma and olfactory function. World J Otorhinolaryngol Head Neck Surg 2018;4(1): $39-45$.

18) Jones SV, Choi DC, Davis M, Ressler KJ. Learning-dependent structural plasticity in the adult olfactory pathway. J Neurosci 2008;28(49):13106-11. 